\title{
Elemental Concentration of Harmattan Dust Sample in Iwo and Oyo Town, South West Nigeria
}

\author{
${ }^{* 1}$ AWEDA, FO; ${ }^{2}$ FALAIYE, OA; ${ }^{1}$ BABATUNDE, GJ \\ ${ }^{1}$ Department of Physics and Solar Energy, Bowen University, Iwo, Osun State, Nigeria \\ ${ }^{2}$ Department of Physics, University of Ilorin, Ilorin, Nigeria \\ *Corresponding Author: francisaweda@gmail.com, aweda.francis@bowenuniversity.edu.ng
}

\begin{abstract}
The period of Harmattan season in Nigeria occurs between the month November and March, this is characterized by dry and dusty north easterly trade wind which blows from the Sahara Desert over Nigeria. Samples of the dust were collected at Iwo $\left(7^{\circ} 63^{\prime} \mathrm{N}, 4^{\circ} 19^{\prime} \mathrm{E}\right)$ and Oyo $\left(8^{\circ} 12^{\prime} \mathrm{N}, 3^{\circ} 42^{\prime} \mathrm{E}\right)$. The samples were analysed using AAS (Atomic Absorption Spectroscopy) machine located at Bowen University Iwo. It was observed that the sample of dust particle collected by the means of distilled water in Iwo town contains $\mathrm{Ca}(22.278 \mathrm{ppm}), \mathrm{Mg}(8.904 \mathrm{ppm})$, and $\mathrm{Fe}$ $(2.133 \mathrm{ppm})$, and the sample of dust particle collected by the means of the first rain water of the year under consideration contains $\mathrm{Ca}(5.494 \mathrm{ppm}), \mathrm{Mg}(6.417 \mathrm{ppm})$, and $\mathrm{Fe}(0.741 \mathrm{ppm})$. For Oyo location, it was observed that the sample of dust particle which was collected by the means of distilled water contains $\mathrm{Ca}(17.701 \mathrm{ppm}), \mathrm{Mg}(11.751 \mathrm{ppm})$, and $\mathrm{Fe}$ (3.729ppm).More so, the sample of dust particle collected by the means of rain water for Oyo contains Ca (4.138ppm), $\mathrm{Mg}(4.074 \mathrm{ppm})$, and Fe $(0.412 \mathrm{ppm})$. The results showed that there was less effect of harmattan dust on human health due to zero or no lead $(\mathrm{Pb})$ content present in the same collected during the period.
\end{abstract}

\section{DOI: $\underline{\text { https://dx.doi.org/10.4314/jasem.v21i7.16 }}$}

Copyright @ 2017 Aweda et al. this is an open access article distributed under the Creative Commons Attribution NonCommercial License (CC-BY-NC), which permits unrestricted use, distribution, and reproduction in any medium, provided the original work is properly cited.

Received 02 October 2017, received in revised form 11 November 2017, accepted 30 November 2017.

Keywords: Harmattan, Distilled Water, Sahara Desert, Iwo and Oyo

Harmattan season occur between the months of November through March of the following year in Nigeria. This period contains dusts laden atmosphere that reduces the visibility and cause domestic and outdoor activities inconvenience in the country. During the period of this study (November to March), the West African region experiences the prevailing north-easterly wind regime known as Harmattan (Falaiye et al., 2003). Harmattan dust lifting, transportation and deposition, occurs naturally (Kalu, 1974, Falaiye et al., 2013), this could be as a result wind transportation that blows the dust from the source and deposition along the trajectory path (Falaiye et al., 2017). Junge, (1979) reported that on the average, it takes about twenty-four hours for the harmattan to reach the Northern part of Nigeria. Bertrand et al., (1979) account for the dust particles deposited over the region where dust plumes predominantly originate from the Bodele depression in the Chad Basin.

During the period of harmattan, it will be observed that human body experience dry skin and some nasal ailments such as Catha that affect the running of nostrils as a result of the dust the blow across the country. This fact has been pointed out by various meteorological observers Samway, (1975). High pressure to the north of Bodele Depressions intensifies the north easterly trade winds leading to an increase entrainment of dust in the Bodele Depression Adedokun et al., (1988). During harmattan, the West African region experiences the prevailing north-easterly wind regime known as harmattan (Falaiye et al., 2003).The dust plumes predominantly originated from the Bodele Depression in the Chad Basin (Bertrand et al., 1979). According to Balogun (1979), two sources of dust plumes were identified and these include the dust originating from the region around Mauritania, Algeria and Morocco which accounts for most dust observed over the Atlantic extending as far west as the Barbados Island and dust originating from the Chad Basin.

\section{MATERIALS AND METHODS}

The total suspended particles (dust sample) matter was collected by the means of distilled water and rain water by allowing harmattan dust particles to settled inside a plastic bowl which contains about 8-10 litters of distilled water and placed about $5 \mathrm{~m}$ above the ground level during harmattan season within the period of 3 months (December 2016 to February 2017). This was taken at two stations (Iwo and Oyo). The first rain for the two stations was also collected by exposing a clean plastic bowl free to air at each station. This confirms that harmattan dust particles 
are mainly particulate matter during its seasons. The effective date for the collection of the dust samples started in December 2016 as a result of lateness in the commencement of the harmattan season and interference of late rainfall during the period of the study. For these research a direct deposition method of dust sample collection was preferred thereby, which account for one of the objectives is to determination of the concentration of the elements in the dust particle in the atmosphere. The samples were digested before taking it for the elemental analysis which AAS (Atomic Absorption Spectroscopy) was used. The digestion process was done in a fume cupboard for safety purpose, by measuring $50 \mathrm{ml}$ of each waste water samples (4 samples), and adding $5 \mathrm{ml}$ of hydrochloric acid, and each were boiled, till they reduced to $20 \mathrm{ml}$, they were all filtered and the filtrates were taken for chemical analysis in which PG990 model buck Scientific Atomic Absorption Spectroscopy (AAS) was used as an analytical technique for trance elemental determinations.

Enrichment Factor (EF) of Chemical Elements Calculation: The analysis of the Enrichment factor was carried out on the sample collected at Oyo and Iwo to differentiate between anothropogenic sources from natural ones. This shows the degree of enrichment of a particular element compared to the relative abundance of those elements in Earth's crust (Behera and Sharma, 2010; Chakrabory and Gupta, 2010).The reference element that was used is $\mathrm{Ca}$ which is assumed to be of crustal origin as reported by Ghosh et al., (2014). Enrichment factor is defined as follows:

$$
E F_{x}=\frac{Y_{x_{S}} / Y_{C_{a_{S}}}}{Y_{x_{c}} / Y_{C_{a_{c}}}} \quad 1
$$

Where $Y_{x_{s}}$ and $Y_{C_{a_{S}}}$ are concentrations of the element $\mathrm{X}$ and $\mathrm{Ca}$ in the samples, $Y_{x_{c}}$ and $Y_{C_{a_{c}}}$ are average concentration in the Earth's upper crust (Taylor et al., 1981; Rudnick and Gao, 2003). By convention (Zhang et al., 2010), if EF $\leq 10$ it is considered that element in aerosol has a significant crustal contribution. This is termed as the non-enriched element. Whereas EF> 10 indicates that element have a significant important proportion derived from noncrustal sources and hence termed as an enriched element as reported by Ghoshet al., 2014.

The $\mathrm{EF}_{\text {crust }}$ values for the following elements $(\mathrm{Ca}$, $\mathrm{Mg}$, and $\mathrm{Fe}$ ) of the earth's upper crust for the dust collected at Oyo and Iwo were calculated using equation 1.0 above.

\section{RESULTS AND DISCUSSION}

The elemental composite and concentrations of the collected and digested harmattan dust sample as revealed by AAS machine are shown in the tables 1 and 2 .

Table 1: The elements present in the samples and their various concentrations in $\mathrm{ppm}$

\begin{tabular}{llll}
\hline Sample & $\mathrm{Ca}(\mathrm{ppm})$ & $\mathrm{Mg}(\mathrm{ppm})$ & $\mathrm{Fe}(\mathrm{ppm})$ \\
\hline Iwo Rain & 5.494 & 6.417 & 0.741 \\
Iwo Harmattan & 22.278 & 8.904 & 2.133 \\
Oyo Rain & 4.138 & 4.074 & 0.412 \\
Oyo Harmattan & 17.701 & 11.751 & 3.729 \\
\hline
\end{tabular}

Table 2: The percentage concentration for the three elements

\begin{tabular}{lllll}
\hline Sample & $\begin{array}{l}\text { Iwo } \\
\text { Dust }\end{array}$ & $\begin{array}{l}\text { Oyo } \\
\text { Dust }\end{array}$ & $\begin{array}{l}\text { Iwo } \\
\text { Rain }\end{array}$ & $\begin{array}{l}\text { Oyo } \\
\text { Rain }\end{array}$ \\
\hline $\begin{array}{l}\text { \% Conc. of } \\
\text { Ca }\end{array}$ & 44.905 & 35.68 & 11.074 & 8.341 \\
$\%$ Conc. of & 30.49 & 53.158 & 10.563 & 5.873 \\
$\begin{array}{l}\text { Fe } \\
\% \text { Conc. of } \\
\mathrm{Mg}\end{array}$ & 28.587 & 37.729 & 20.603 & 13.08 \\
\hline
\end{tabular}

At the end of the analysis, the element found in the Harmattan dust for Iwo and Oyo stations includes: Iron $(\mathrm{Fe})$, Magnesium $(\mathrm{Mg})$ and Calcium $(\mathrm{Ca})$, in which they are of different concentrations. For Iwo, the concentration of Calcium (Ca) gotten from the dust particle in the distilled water sample (Iwo Harmattan) was 22.278ppm while in the rain sample (Iwo rain) was 5.493ppm. Magnesium (Mg) concentration gotten from the dust particle in the distilled water sample (Iwo Harmattan) was $8.904 \mathrm{ppm}$ while in the rain sample (Iwo rain) $5.493 \mathrm{ppm}$. Iron concentration gotten from the dust particle in the distilled water (Iwo Harmattan) was $2.133 \mathrm{ppm}$ while in the rain sample (Iwo rain) was $0.741 \mathrm{ppm}$. As shown in table 1.0 above.

For Oyo, the concentration of Calcium (Ca) gotten from the dust particle in the distilled water sample (Oyo Harmattan) was $17.701 \mathrm{ppm}$ while in the rain sample (Oyo rain) was 4.138ppm. Magnesium (Mg) concentration gotten from the dust particle in the distilled water sample (Oyo Harmattan) was $11.751 \mathrm{ppm}$ while in the rain sample (Oyo rain) was $4.074 \mathrm{ppm}$. Iron concentration gotten from the dust particle in the distilled water sample (Oyo Harmattan) was $3.729 \mathrm{ppm}$ while in the rain sample (Oyo rain) was $0.412 \mathrm{ppm}$. These results are shown in the table 1.0 above. The maximum element that could be detected from the AAS machine used at Department of Chemistry Bowen University was eleven elements due to the number filter that were present in the Department. Meanwhile, the machine just found three elements from the sample that were analyzed. Other elements were not found as results of 
not present in the sample collected at the two stations because of the deposition during the transportation

from the Sahara desert.

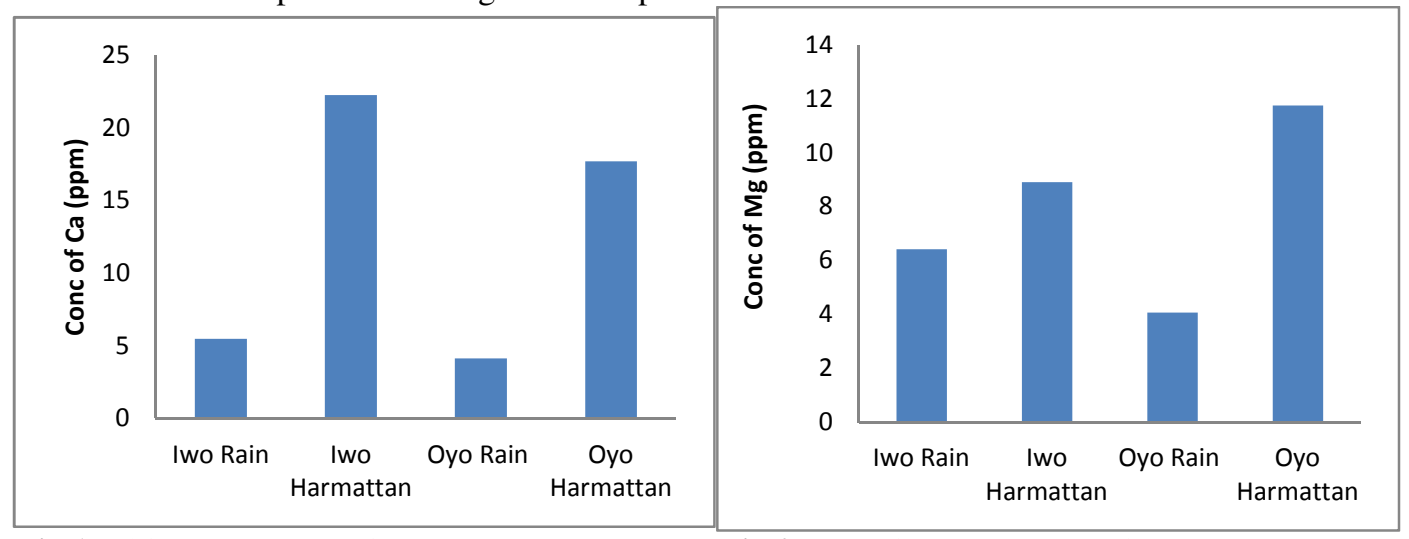

Fig. 1:Calcium $(\mathrm{Ca})$ concentration

Fig. 2: Magnesium (Mg) concentration

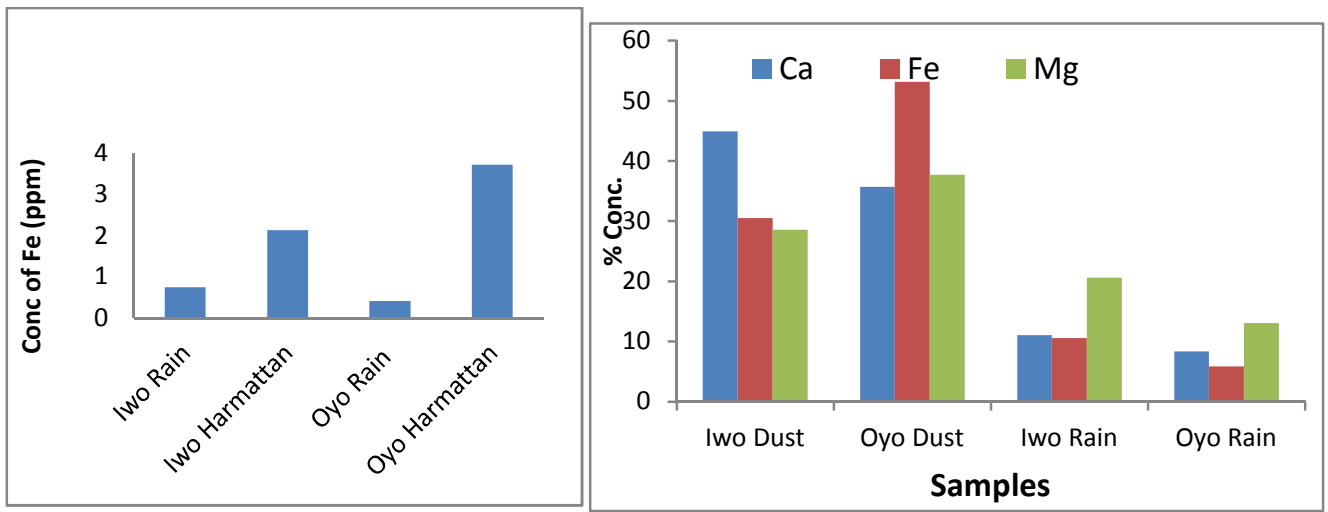

Fig3: Iron (Fe) concentration

Fig. 4: Percentage Concentration of element

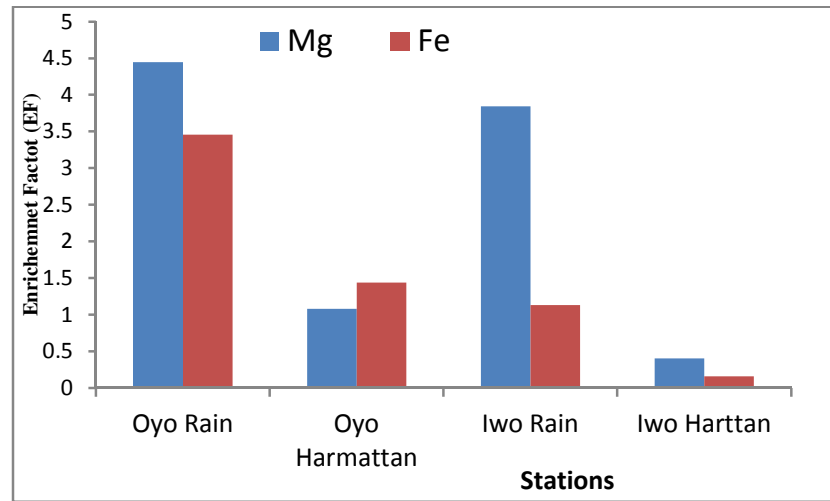

Fig. 5: Enrichment factor of elements referred to crust dust in total size particle sample.

Figure 1.0 shows that Iwo Harmattan has the highest percentage concentration of Calcium $(22.278 \%)$ and Oyo rain has the lowest percentage concentration of calcium $(4.138 \%)$, therefore, Harmattan dust in Iwo town has more concentration of Calcium than that of Oyo town. Figure 2.0 was observed, that Oyo Harmattan has the highest percentage concentration of Magnesium (11.751\%) and Oyo rain has the lowest percentage concentration (4.074\%). Therefore, Harmattan dust in Oyo town has more concentration of Magnesium than what was observed at Iwo. Figure 3.0 was observed, that Oyo Harmattan has the highest percentage concentration of Iron (3.729\%) and Oyo rain has the lowest percentage concentration which is $(0.412 \%)$, therefore, Harmattan dust in Oyo town has more concentration of Iron than that of Iwo town. 
Figure 4.0 shows that Iron have highest concentration of the dust particles as compared with other elements present in the sample collected across each location. This could be attributed to vehicular movement and some domestic activities that may be taking place in the location.

Figure 5.0 above showed the Enrichment Factor (EF) for the stations Iwo and Oyo in terms of their sample collected. It was observed that the EF of Oyo Rain in terms of Magnesium (Mg) have the highest concentration $(4.4487 \mathrm{ppm})$, this was followed by what was recorded in Iwo rain (3.8446pp). For this reason it was observed that the concentration of harmattan dust collected at the two stations have more of $\mathrm{Mg}$ in terms of the Enrichment factor. The least of this was recorded in Iwo harmattan $(0.4005 \mathrm{ppm})$. Meanwhile, for Iron $(\mathrm{Fe})$, it was observed that the concentration for the EF have the highest value in Oyo rain (3.4583pp), which was followed by the concentration of Oyo harmattan (1.4372ppm), this was followed by what was recorded in Iwo rain (1.1270ppm), while the least of Fe concentration of the EF was recorded to be in Iwo harmattan $(0.1572 \mathrm{ppm})$.

Conclusion: The elements present in the harmattan dust are expected to comprise of light and heavy metals. Heavy metals are known to be harmful to human health if they are more than the recommended concentration value by World Health Organization (WHO) standard. Iwo and Oyo are expected to have lower values of the dust concentrations due to the drop of the dust particle during its transportation from the Sahara desert. Therefore, the harmattan dust that blows across the stations under consideration has lower concentration of the element observed.

Acknowledgement: The author wishes to acknowledge the Department of Chemistry, Bowen University Iwo for the privilege given towards the analysis of samples.

\section{REFERENCES}

Adedokun, JA; Adeyefa, ZD; Okogbue, E; Holmgren, B(1988).Measurements of Solar and Longwave Radiation over Ile- Ife, Nigeria.AIP Conf. Proc. 320, 179-190.

Balogun, EE (1974).The Phenomenology of the Atmosphere over West African.Proceedingsof Ghana Scope's Conference on Environment and Development in West African.Ghana Academy of Arts and Science.19-31.

Behera, SN and Sharma, M( 2010).Reconstructing Primary and Secondary Components of $\mathrm{PM}_{2.5}$ Composition for an Urban Atmosphere. Aerosol Sci. Technol.44: 983992.

Bertrand, J; Cerf, A and Domergue, JK (1979).Repartition in Space and Time of Dust HazeSouth of the Sahara, W.M.D.538: 409-415.

Chakraborty, Aand Gupta, T (2010).Chemical Characterization and Source Apportionment of Submicron(PM1) Aerosol in Kanpur Region, India.Aerosol Air Qual. Res.10: 433-445.

Falaiye, OA; Aro, TO and Babatunde, EB (2003).Interannual Variation of Aerosol OpticalDepth at Ilorin, a Central State of Nigeria, ZumaJourn.of Pure and App. Science.5(2): 197-204.

Falaiye, OA; Yakubu, AT; Aweda, FO and Abimbola, OJ (2013). Mineralogical Characteristics of Harmattan Dust in Ilorin, Sub-Sahara Africa.Ife Journal of Science.15(1): 175-181.

Falaiye, OA; Aweda, FO; and Yakubu, A T (2017).Harmattan Dust Mass Over Ilorin a Guinea Savanna African City. FUTA Journal of Research in Sciences.13(1):158- 167.

Ghosh, S; Tarun, G; Nikhil, R; Abhishek, G; Amit, M; Sachchida, N T;Debajyot, P;Vinod, T;Om, P;Deepika, B;Anubhav, KD;Daya, SK;Rosalin, D;Sumit, KM (2014).Chemical Characterization of Summertime Dust Events at Kanpur: Insight intothe Sources and Level of Mixing with Anthropogenic Emissions.Aerosol and Air Quality Research.14: 879891.

Junge, C (1979).The importance of mineral dust as atmospheric constituents. Scientific Committee on Problems of the Environment SCOPE Report: 14, John Wiley and sons, Chichester and New York.

Kalu, AE (1979).The African dust plume: Its characteristics and propagation across West -Africa in winter. In Morales, C. (Ed.) Saharan dust Mobilization Transport Deposit,SCOPE 14, John Wiley.95-118.

Rudnick, R.and Gao, S. (2003): Composition of the Continental Crust. Treat. Geochem.3: 1-64.

Samway, J(1975).A Synoptic Account of an Occurrence of Dense Harmattan Dust in Kano in February 1974.Savanna.4:187-190.

Taylor, S; McLennan, S; Armstrong, Rand Tarney, J (1981).The Composition and Evolutionof theContinental Crust: Rare Earth Element Evidence fromSedimentary Rocks. Philos. Trans. R. Soc. London, Ser.A. 301: 381-399.

Taylor, SR and McLennan, SM (1985).The Continental Crust: It's Composition and Evolution. Blackwell Scientific, Oxford.

Zhang, R;Shen, Z;Cheng, T;Zhang, Mand Liu, Y(2010). The Elemental Composition of Atmospheric Particles atBeijing during Asian Dust Events in Spring 2004.Aerosol Air Qual. Res. 10: 67-75. 